\title{
Efek Afrodisiaka Ekstrak Kulit Batang Sanrego (Lunasia Amara Blanco) Terhadap Mencit Jantan (Mus musculus)
}

\author{
Hamsidar Hasan ${ }^{1}$, Juliyanty Akuba² Beatrice Nathania Wilkinson ${ }^{3}$, \\ 1,2,3 Jurusan Farmasi, Fakultas Olahraga dan Kesehatan, Universitas Negeri Gorontalo, Gorontalo \\ ${ }^{*}$ E-mail: hamsadar_hasan@yahoo.com;
}

\section{Article Info:}

Received: 10 Juli 2021

in revised form: 18 Juli 2021

Accepted: 29 Agustus 2021

Available Online: 29 Agustus 2021

\begin{tabular}{l} 
Keywords: \\
Sanrego Lunasia \\
Afrodisiaka \\
Mice \\
\hline Corresponding Author: \\
Hamsidar Hasan \\
Jurusan Farmasi \\
Fakultas Olahraga dan \\
Kesehatan \\
Universitas Negeri Gorontalo \\
Gorontalo \\
E-mail: \\
hamsidar_hasan@yahoo.com
\end{tabular}

\begin{abstract}
Sanrego (Lunasia amara Blanco) is a medicinal plant used as Aphrodisiac by the people os Fouth Sulawesi. This study aimed to discover the aphrodisiac effect of n-hexane, chloroform, ethyl acetate, and methanol extracts of Sanrego (Lunasia amara Blanco) bark as well as to determine the dose required to provide an aphrodisiac effect in male house mice. In addition, the extraction method applied in this study was multilevel maceration using increasing polarity for n-hexane, chloform, ethyl acetate, and metanol. The observation on house mice and the calculation of the number of Introducing, Climbing, and Coitus for five days was conducted. Then, the data were analyzed using One Way ANOVA with SPSS. Phytochemical screening revealed that the steroid compound contained in n-hexane, chloroform, ethyl acetate, and methanol extracts; flavonoid contained in chloroform, ethyl acetate, and methanol extracts; tannin contained in ethyl acetate, and methanol extracts; and alkaloid contained in methanol extract. Equally important, the extract that provided the aphrodisiac effect was methanol extract, and the required doses to provide aphrodisiac effect in male house mice were $35 \mathrm{mg} / \mathrm{kgBW}$ and $70 \mathrm{mg} / \mathrm{kgBW}$. Data analysis using One Way ANOVA obtained that the p-value was lower than 0,01 $(p<0,01)$ with a significant level of $99 \%$. The extract that provided the aphrodisiac effect was methanol extract, and the required doses to provide aphrodisiac effect in male house mice were $35 \mathrm{mg} / \mathrm{kgBW}$ and $70 \mathrm{mg} / \mathrm{kgBW}$.
\end{abstract}

Copyright (C) 2021 IJPE-UNG

This open access article is distributed under a Creative Commons Attribution (CC-BY-NC-SA) 4.0 International license.

How to cite (APA $6^{\text {th }}$ Style):

Hasan,Hamsidar., Akuba, J., Wilkinson.N.B. (2021). Efek Afrodisiaka Ekstrak Kulit Batang Sanrego (Lunasia amara Blanco) Terhadap Mencit Jantan (Mus musculus). Indonesian Journal of Pharmaceutical (e-Journal),1(3), 152-157. 


\begin{abstract}
ABSTRAK
Sanrego (Lunasia amara Blanco) merupakan salah satu jenis tanaman yang digunakan sebagai afrodisiaka oleh masyarakat Sulawesi Selatan. Penelitian ini bertujuan untuk mengetahui efek afrodisiaka dari ekstrak n-heksan, kloroform, etil asetat dan metanol kulit batang Sanrego (Lunasia amara Blanco) serta mengetahui dosis yang diperlukan untuk memberikan efek afrodisiaka pada mencit jantan. Metode ekstraksi yang digunakan adalah maserasi bertingkat menggunakan pelarut dengan kepolaran meningkat yaitu n-heksan, kloroform, etil asetat dan metanol. Dilakukan pengamatan pada mencit serta menghitung jumlah Introduksi (Pendekatan), Climbing(Penunggangan) dan Coitus(Senggama) selama 5 hari. Data dianalisis menggunakan SPSS One way Anova. Hasil penelitian skrining fitokimia menunjukkan adanya senyawa steroid yang terkandung dalam ekstrak N-Heksan, kloroform, etil asetat dan metanol, terdapat senyawa flavonoid dalam ekstrak kloroform, etil asetat, metanol. Terdapat senyawa tanin dalam ekstrak etil asetat dan metanol dan terdapat senyawa alkaloid dalam ekstrak metanol. Ekstrak yang memberikan efek afrodisiaka yaitu ekstrak metanol dan dosis yang diperlukan untuk memberikan efek afrodisiaka pada mencit yaitu $35 \mathrm{mg} / \mathrm{kgBB}$ dan $70 \mathrm{mg} / \mathrm{kgBB}$. Hasil analisis data One way Anova $(\mathrm{p}<0,01)$ dengan tingkat kepercayaan $99 \%$
\end{abstract}

Kata Kunci: Kulit batang Lunasia, Afrodisiaka, Mencit

\title{
1. Pendahuluan
}

Impotensi ialah belum mampunya seseorang lelaki dalam ereksi maupun belum mampunya menjaga ereksi. Banyaknya penderita impotensi enggan maupun merasa malu ketika mengungkapkan masalahnya terhadap orang lain, sebab diharap termasuk mengungkapkan aib sendiri serta keluarga sampai sangat dipilih menelusuri perawatan individual. Perihal tersebut mengajak pemakaian afrodisiaka untuk alternative perawatannya hingga banyak diminati, khususnya afrodisiaka tradisional yang asalnya melalui produk-produk alamiah misalnya tanaman, hewani serta yang lainnya. Disamping itu, obat racikan relatif terjangkau pula cepat didapatkan dalam pengaruh bawaan yang relative rendah, ketika dipakai dengan sesuai juga rasionalis.

Pada Indonesia kekayaan alamnya selalu dilestarikan meninjau manfaat serta fungsi tanaman bisa memperoleh fungsi terhadap kesehatan bermasyarakat. Tanam-tanaman termasuk suatu sumber zat produk alamiah hayati yang berpegangan dalam peranan terpenting pada manfaat senyawa kimiawi berkhasiat.

Sanrego (Lunasia amara Blanco) merupakan salah satu jenis tanaman yang digunakan sebagai afrodisiaka oleh masyarakat Sulawesi Selatan, tepatnya di Kabupaten Bone, Kecamatan Palattae. Habitus tanaman seperti pepohonan, hidup menegak, tingginya sekitar 12 meter, berbatang kayu, berbentuk bulat, permukaan berbatang licin. Daunnya tunggal, membentuk bulat atau sedikit membentuk jantung, ujung serta pangkalnya meruncing, permukaannya kasar berlekukan, daun bersilangan dengan sistem persilangan daun menyirip, warna hijau kebiruan. Tanaman tersebut tumbuh tersebar pada Pulau Sulawesi sampai Pulau Papua bahagian barat.

Kandungan senyawa aktif tersebut diantaranya kelompok alkaloid, yaitu lunakrinida, lunakrina, lunasina serta lunania; serta kalsium oksalat, asam formiat, steroid juga glukosida (Subehan,1999)[9].

Penggunaan sanrego sebagai afrodisiaka dimulai pada informasi yang dikembangkan pada masyarakat mengenai seekor kuda jantan yang menjilati kayu sanrego serta mengkonsumsi daun dan kulit berkayu tersebut, selanjutnya mendapatkan pertambahan libido dengan kekuatan seksual. Warga sekitar selajutnya ditarik untuk menggunakan tumbuhan tersebut dalam perendaman batang kayu sanrego pada air hingga semalam serta meminum air rendamannya. Ternyata bisa dirasakan bahwa rendaman kayu sanrego memberi dampak afrodisiaka yang sangat sempurna. Penggunaan kayu sanrego sebagai afrodisiaka sekarang ini telah meluas ke daerah lain, bahkan telah diperjual belikan secara bebas dan laku keras walaupun tanpa disertai 
label dan brosur yang mempromosikannya. Bagian tanaman yang digunakan pada umumnya kar dan kayunya, tetapi ada juga menggunakan daunnya.

Berdasarkan latar belakang tersebut maka dilakukan penelitian ini, untuk mengetahui seberapa besar efek afrodisiaka kulit batang sanrego pada mencit jantan.

2. Metode Penelitian

Desain Penelitian

Desain penelitian yang digunakan dalah eksperimental laboratorium. Eksperimental laboratorium dilakukan secara in vivo.

\subsection{Alat dan Bahan}

Alat-alat yang digunakan dalam penelitian ini yaitu alat evaporator, alat maserator, batang pengaduk, botol plastik, dispo, gelas ukur, kain saring, kandang mencit, neraca analitik (ohaus), selang NGT.

Bahan yang digunakan dalam penelitian ini adalah amoniak, asam asetat anhidrat, asam sulfat $2 \mathrm{~N}$, etanol $70 \%$, etil asetat, $\mathrm{FeCl}$ (III) $10 \%, \mathrm{H}_{2} \mathrm{SO}_{4}$ pekat, $\mathrm{HCl} 2 \mathrm{~N}$, kertas saring, kloroform, Liebermann-Burchard, methanol, n-heksan, Na-CMC, $\mathrm{NaOH}$, Obat Viagra, pereaksi mayer, pereaksi dragendorff, pereaksi wagner, serbuk kulit batang Sanrego (Lunasia amara Blanco), serbuk Mg

Prosedur Kerja

Preparasi Sampel

Kulit batang tumbuhan Sanrego (Lunasia amara Blanco) diperoleh dari Taman Nasional Babulu (Bantimurung, Bulusaraung), Sulawesi Selatan, kemudian dicuci bersih dengan air mengalir, dikeringkan dibawah sinar matahari langsung lalu diblender menjadi serbuk.

Dilakukan maserasi bertingkat untuk sampel serbuk Sanrego. Pelarut yang dipakai ialah pelarut yang kepolarannya selalu bertambah dimana n-heksan, kloroform, etil asetat dan methanol. Serbuk simplisia ditimbang $600 \mathrm{~g}$ dimasukkan ke dalam toples bening. Meserasi pertama serbuk sanrego dimaserasi dengan pelarut n-heksan selama 3×24 jam sambil sesekali dilakukan pengadukan. Setelah $3 \times 24$ jam residu terpisah melalui filtratnya juga residu simplisia dilakukan pengeringan. Setelah kering, residu kembali dimaserasi dengan kloroform selama $3 \times 24$ jam sambil sesekali dilakukan pengadukan, setelah 3×24 jam dipisahkan filtrat dan residu. Residu dikeringkan lalu dimaserasi dengan etil asetat dengan metode yang sama dan begitu juga untuk pelarut methanol.

Skrining Fitokimia

Dilakukan pengujian skrining fitokimia ekstrak kulit batang Sanrego (Lunasia amara Blanco) meliputi uji alkaloid, flavonoid, saponin, tanin dan steroid.

Penyiapan Hewan Uji

Hewan uji yang digunakan dalam penelitian ini adalah mencit putih jantan dan betina (Mus musculus) dengan berat badan 20-30 gram yang belum pernah dilakukan perlakuan terhadap beberapa obat sebanyak 22 ekor. Mencit diaklimatisasi dan diberi makan standar. Setelah itu dikelompokkan menjadi 5 kelompok.

Penentuan dan Pembuatan Konsentrasi

Mencit dibagi menjadi 5 kelompok. Kelompok 1 sebagai kelompok kontrol negatif menggunakan Na-CMC 0,5\%. Kelompok 2 sebagai kelompok kontrol positif menggunakan obat Viagra dan kelompok 3, 4 dan 5 sebagai kelompok perlakuan masing - masing menggunakan ekstrak kulit batang Sanrego dengan dosis 35 mg/kgBB, 70 mg/kgBB dan 105 mg/kgBB.

Pembuatan Na-CMC yakni menimbang 0,5 g kemudian dituangkan kedalam aquadest sebanyak 7,5 mL digerus hingga homogen dan ditambahkan air hingga $100 \mathrm{~mL}$

Suspensi Viagra dibuat dengan cara menggerus Viagra $100 \mathrm{mg}$ sampai halus lalu timbang sebanyak 0,31 g kemudian tambahkan Na-CMC 0,5 g gerus perlahan-lahan hingga homogen. Setelah homogen dimasukkan kedalam wadah dan ditambahkan $100 \mathrm{~mL}$ aquadest.

Suspensi ekstrak kulit batang Sanrego (Lunasia amara Blanco) ditimbang terlebih dahulu dengan dosis $35 \mathrm{mg} / \mathrm{kgBB}, 70 \mathrm{mg} / \mathrm{kgBB}, 105 \mathrm{mg} / \mathrm{kgBB}$, kemudian dilarutkan dalam 10mL NaCMC. 


\section{Uji Perilaku Hewan Mencit Jantan}

Setiap golongan mencit jantan diamankan pada suatu kandang. Mencit jantan yang sudah diberikan perlakuan dimasukkan pada tempat yang sangat leluasa. Sesudah beradaptasi hingga 5 menit, bisa digabungkan bersama mencit betina, diamati pada waktu malam hari pada jam 18.00-20.00 selama 5 hari berturut-turut mencakup banyaknya pendekatan (Introduksi), Climbing (Penunggangan) dan Coitus (Senggama)

Analisis Data

Data dari hasil penelitian ini dianalisis secara statistik dengan ANOVA dengan tingkat kepercayaan $99 \%$.

3. Hasil dan Pembahasan

Hasil Ekstrak

Tabel 1. Hasil Ekstrak

\begin{tabular}{cccc}
\hline Berat Sampel (g) & Pelarut & Berat Ekstrak (gram) & Rendamen \\
\hline 600 & N-Heksan & 62 & $10,33 \%$ \\
\hline 546 & Kloroform & 64 & $11,72 \%$ \\
\hline 502 & Etil Asetat & 59 & $11,75 \%$ \\
\hline 480 & Metanol & 58 & $12,08 \%$ \\
\hline
\end{tabular}

Tabel 1 menunjukkan hasil rendemen setiap ekstrak. Menurut Depkes RI (2000)[5], hasil rendemen yang baik berada diantara 10-15\%.[1] Data hasil rendemen tersebut ada hubungannya dengan senyawa aktif yang terkandung dalam suatu sampel sehingga apabila jumlah rendemen semakin banyak maka jumlah senyawa aktif yang terkandung dalam sampel juga semakin banyak. Sebagaimana menurut Harbone (1987)[7] bahwa tingginya senyawa aktif yang terdapat pada suatu sampel ditunjukkan dari jumlah rendemen yang dihasilkan.

Hasil Skrining Fitokimia

Tabel 2. Hasil Skrining Fitokimia Ekstrak Kulit Batang Sanrego (Lunasia amara Blanco)

\begin{tabular}{lccccc}
\hline & Alkaloid & Steroid & Flavonoid & Saponin & Tanin \\
\hline N-Heksan & - & + & - & - & - \\
\hline Kloroform & - & + & + & - & - \\
\hline Etil Asetat & - & ++ & + & - & - \\
\hline Metanol & - & + & + & - & -
\end{tabular}

Pada tabel 2 menunjukkan hanya ekstrak kental metanol yang positif mengandung alkaloid sehingga ekstrak kental metanol yang dipakai untuk menguji efek afrodisiaka. Berdasarkan Prescott et al (2006)[8], sanrego mengandung alkaloid yang memiliki dampak antibakteri, anti $\mathrm{TBC}$, penguatan otot jantung serta afrodisiaka (obat kuat lelaki). 
Tabel 3 Introduksi

\begin{tabular}{|c|c|c|c|c|c|}
\hline \multirow{2}{*}{$\begin{array}{l}\text { Kelompok } \\
\text { Perlakuan }\end{array}$} & \multicolumn{5}{|c|}{ Introduksi } \\
\hline & $\begin{array}{l}\text { Hari 1 } \\
5\end{array}$ & Hari 2 & Hari 3 & Hari 4 & Hari \\
\hline Na-CMC & - & 1 & $\mathbf{1}$ & 1 & - \\
\hline Viagra & 6 & 9 & 10 & 9 & 3 \\
\hline Dosis 1 & 11 & 18 & 17 & 13 & 9 \\
\hline Dosis 2 & 10 & 19 & 15 & 13 & 8 \\
\hline Dosis 3 & 5 & 8 & 9 & 8 & 4 \\
\hline \multicolumn{6}{|c|}{ Tabel 4 Climbing } \\
\hline \multirow{2}{*}{$\begin{array}{l}\text { Kelompok } \\
\text { Perlakuan }\end{array}$} & \multicolumn{5}{|c|}{ Climbing } \\
\hline & $\begin{array}{l}\text { Hari 1 } \\
5\end{array}$ & Hari 2 & Hari 3 & Hari 4 & Hari \\
\hline Na-CMC & - & 1 & - & - & - \\
\hline Viagra & 3 & 5 & 6 & 5 & 2 \\
\hline Dosis 1 & 5 & 9 & 7 & 5 & 2 \\
\hline Dosis 2 & 3 & 8 & 6 & 7 & 3 \\
\hline Dosis 3 & 2 & 4 & 5 & 4 & 2 \\
\hline
\end{tabular}

Berdasarkan tabel 3 dan 4 dapat dilihat bahwa dosis 1 dan 2 memberikan efek lebih baik dari dosis 3 dan Viagra. Dosis 1 memberikan efek introduksi paling baik sedangkan dosis 2 memberikan efek climbing yang paling baik.

Hasil Statistik

Tabel 5 Hasil Uji statistik Introduksi (Pendekatan)

\begin{tabular}{|c|c|c|c|c|}
\hline Kelompok & $\mathbf{N}$ & $\mathbf{A}$ & Sig & Ket \\
\hline \multicolumn{5}{|l|}{ Na-CMC } \\
\hline $\begin{array}{l}\text { Viagra } \\
\text { sig<a }\end{array}$ & 5 & 0,01 & 0,000 & \\
\hline Dosis 1 & & & & \\
\hline Dosis 2 & & & & \\
\hline Dosis 3 & & & & \\
\hline
\end{tabular}

Tabel 6 Hasil Uji Statistik Climbing

\begin{tabular}{llclr}
\hline Kelompok & N & A & Sig & Ket \\
\hline Na-CMC & & & 0,000 \\
Viagra & 5 & 0,01 & \\
sig<a & & & \\
Dosis 1 & & & \\
Dosis 2 & & & \\
Dosis 3 & & & \\
\hline
\end{tabular}

Uji statistik dilakukan untuk melihat nilai signifikan dan memastikan kebenaran suatu hipotesis yang dibuat. Pada pengujian ini diambil nilai tingkat kepercayaan $99 \%$ atau 0,01. Untuk pemilihan hipotesis dilakukan dengan membandingkan hasil hitungan ( $p$ value) terhadap nilai standar signifikan, h0 diterima apabila nilai 0 value $>$ nilai standar signifikan dan h0 ditolak apabila nilai $\mathrm{p}$ value< nilai standar signifikan (Fitria $d k k, 2016)$.[6]

Berdasarkan uji statistik one way Anova yang telah dilakukan, untuk melihat perbandingan antara kelompok perlakuan diperoleh nilai p kurang dari 0,01 oleh karena itu dapat dikatakan bahwa hasil efek afrodisiaka antara kelompok perlakuan signifikan. 


\section{Kesimpulan}

Berdasarkan hasil penelitian dapat disimpulkan bahwa, dari ekstrak n-heksan, kloroform, etil asetat dan metanol ekstrak kulit batang Sanrego (Lunasia amara Blanco), yang memberikan efek afrodisiaka pada mencit dan dosis optimal yang dapat digunakan untuk memberikan efek afrodisiaka pada mencit jantan yaitu sebesar $35 \mathrm{mg} / \mathrm{kgBB}$ dan $70 \mathrm{mg} / \mathrm{kgBB}$.

Referensi:

[1] Anna, Y , Arnida. 2011. Aktivitas Afrodisiaka Fraksi n-Butanol Cawat Hanoman (Labisia pumila) Terhadap Mencit Jantan. FMIPA Universitas Lambung Mangkurat: Kalimantan Selatan [2] Ansel, 1985. Pengantar bentuk sediaan farmasi edisi ke empat. Diterjemahkan oleh Faridah Ibrahim. Universitas Indonesia press : Jakarta

[3] Arnida, Imono, A, Donitus, Subagus, Wahyono. 2003. Isolasi Frasi Aktif Efek Afrodisiaka dari kayu Sanrego (Lunasia amara Blanco). Jurusan Farmasi Universitas Pancasakti: Makassar

[4] Arzani, M, N. 1990. Efek Androgen Suatu Ramuan Tradisional Kalimantan Yang Biasa Digunakan Sebagai Obat Kuat Lelaki. Medika 10(16)819: Kalimantan

[5] Depkes RI, 2000. Parameter Standar Umum Ekstrak Tumbuhan Obat. Departemen

Kesehatan RI. 10-11. Jakarta

[6] Fitria $d k k$ (24 Oktober 2016). Gambaran Tingkat Depresi Pada Pasien Ginjal Kronik Yang Menjalanai Hemodialisis di RSUP Dr. M Jamil Padan. http://jurnal.fk.unand.ac.id.

[7] Harborne, J,B. (1987). Metode Fitokimia. Penuntun Cara Modern Menganalisa Tumbuhan Edisi II. Bandung: ITB.

[8] Presscott et al. (2006). Lunacridine from Lunasia amara is a DNA Intercalating topoisomerase II inhibitor, Journal of Pharmacology 109. Pp, 289 - 294.

[9] Subehan. (1999). Pemeriksaan Farmakognosi dan dan Uji Kromatografi Lapis Tipis Tumbuhan Lunasia amara Blanco. Jurusan Farmasi. Fakultas MIPA Universitas Hasanuddin: Makassar

[10] Sudjadi. 1988. Metode Pemisahan hal. 167-177. Fakultas Farmasi. Universitas Gadjah Mada: Yogyakarta

[11] Sutir, Fitriadi. 2011. Analisis Kandungan Senyawa Flavonoid Total Dalam Sediaan Cair Kasumba Turate (Carthamus tinctorius Linn.) Secara Spektrofotometri UV-Vis. Universitas Hasanuddin: Makassar

[12] Tantu, Sitti Khadijah. 2018. Pengaruh Pemberian Ekstrak Daun Seledri (Apium graveolens) Kombinasi Simvastatin Terhadap Penurunan Kadar Kolestrol Total Pada Mencit Putih Jantan. Universitas Negeri Gorontalo: Gorontalo

[13] Victor, dkk. 2019. Efek Afrodisiaka Ekstrak Euryco® (Eurycoma longifolia Jack) Terhadap sexual Behaviour Tikus Putih Jantan Wistar. Universitas Gadjah Mada: Yogyakarta

[14] Vincentia, Kristiani; Filia, Irawati, Halim. 2014. Pengaruh Konsentrasi Etanol dan Waktu Maserasi Terhadap Perolehan Fenolik, Flavonoid dan Aktivitas Antioksidan Ekstrak rambut Jagung. Jurusan Teknik Kimia. Universitas Katolik Widya Mandala: Surabaya

[15] Winarti, Sri. 2010. Makanan Fungional. Graha Ilmu: Yogyakarta 